\title{
ENGAGING CHINA
}

A NANCY BERNKOPF TUCKER AND WARREN I. COHEN BOOK ON AMERICAN-EAST ASIAN RELATIONS 


\title{
A NANCY BERNKOPF TUCKER AND WARREN I. COHEN BOOK ON AMERICAN-EAST ASIAN RELATIONS
}

\author{
Edited by Thomas J. Christensen \\ Mark Philip Bradley \\ Rosemary Foot
}

Michael J. Green, By More Than Providence: Grand Strategy and American Power in the Asia Pacific Since 1783

Jeanne Guillemin, Hidden Atrocities: Japanese Germ Warfare and American

Obstruction of Justice at the Tokyo Trial 
Andrew B. Kennedy, The Conflicted Superpower: America's Collaboration with China and India in Global Innovation

Nancy Bernkopf Tucker was a historian of American diplomacy whose work focused on American-East Asian relations. She published seven books, including the prize-winning Uncertain Friendships: Taiwan, Hong Kong, and the United States, 1945-1992. Her articles and essays appeared in countless journals and anthologies, including the American Historical Review, Diplomatic History, Foreign Affairs, and the Journal of American History. In addition to teaching at Colgate and Georgetown (where she was the first woman to be awarded tenure in the School of Foreign Service), she served on the China desk of the Department of State and in the American embassy in Beijing. When the Office of the Director of National Intelligence was created, she was chosen to serve as the first assistant deputy director of national intelligence for analytic integrity and standards and ombudsman, and she was awarded the National Intelligence Medal of Achievement in 2007. To honor her, in 2012 the Woodrow Wilson International Center for Scholars established an annual Nancy Bernkopf Tucker Memorial Lecture on U.S.-East Asian Relations.

Warren I. Cohen is university distinguished professor emeritus at Michigan State University and the University of Maryland, Baltimore County, and a senior scholar in the Asia Program of the Woodrow Wilson Center. He has written thirteen books and edited eight others. He served as a line officer in the U.S. Pacific Fleet, editor of Diplomatic History, president of the Society for Historians of American Foreign Relations, and chairman of the Department of State Advisory Committee on Historical Diplomatic Documentation. In addition to scholarly publications, he has written for the Atlantic, the Baltimore Sun, the Christian Science Monitor, Dissent, Foreign Affairs, the International Herald Tribune, the Los Angeles Times, the Nation, the New York Times, the Times Literary Supplement, and the Washington Post. He has also been a consultant on Chinese affairs to various government organizations. 



\title{
ENGAGING CHINA
}

\section{Fifty Years of}

Sino-American Relations

\author{
EDITED BY
}

ANNE F. THURSTON

Columbia University Press

New York 


\section{叫 \\ Columbia University Press \\ Publishers Since 1893 \\ New York Chichester, West Sussex \\ cup.columbia.edu \\ Copyright $\odot 2021$ Columbia University Press \\ All rights reserved}

\section{Library of Congress Cataloging-in-Publication Data}

Names: Thurston, Anne F., editor.

Title: Engaging China : fifty years of Sino-American relations / edited by Anne F. Thurston.

Other titles: Fifty years of Sino-American relations

Description: New York : Columbia University Press, [2021] |

Includes bibliographical references and index.

Identifiers: LCCN 2021001762 (print) | LCCN 2021001763 (ebook) |

ISBN 9780231201285 (hardback) | ISBN 9780231201292 (trade paperback) |

ISBN 9780231554022 (ebook)

Subjects: LCSH: United States-Foreign relations-China. | China-

Foreign relations-United States. | China-Foreign relations-1976- |

United States-Foreign relations-1945-1989. | United States-Foreign

relations-1989-

Classification: LCC E183.8.C6 E54 2021 (print) | LCC E183.8.C6 (ebook) |

DDC 327.73051-dc23

LC record available at https://lccn.loc.gov/2021001762

LC ebook record available at https://lccn.loc.gov/2021001763

Columbia University Press books are printed on permanent and durable acid-free paper.

Printed in the United States of America

Cover image: Mao and Nixon in 1972.

Credit: Photo ๑ Leonard de Selva / Bridgeman Images

Cover design: Lisa Hamm 
To David M. (Mike) Lampton

With gratitude, admiration, and respect

For your lifetime of contributions to the China field

$\approx$ 
